\title{
In Vitro and in Vivo Evaluation of Anti-trypanosomal Activity of Stem Bark of Ximenia Americana
}

\author{
Maikai V.A \\ College of Agriculture and Animal Science, Ahmadu Bello University \\ P.M.B.2134, Mando - Kaduna, Nigeria \\ E-mail: ambrosev2003@yahoo.com
}

\begin{abstract}
The in vitro and in vivo anti-trypanosomal activity of aqueous and methanolic extracts of bark of Ximenia americana was examined in mice experimentally infected with Trypanosoma congolense. Thirty (30) healthy mice were infected with $T$. congolense at $10^{4}$ and subsequently treated in vitro with aqueous, methanolic and Diminavet $^{\mathrm{R}}$ extract at 3,6 , and $9 \mathrm{mg} / \mathrm{ml}$ and in vivo with aqueous stem bark extract at 50, 100, $200 \mathrm{and} 300 \mathrm{mg} / \mathrm{Kg}$ body weight and Diminavet ${ }^{\mathrm{R}}$ at $3.5 \mathrm{mg} / \mathrm{kg}$ body weight respectively. The result showed that in vitro incubation of infected blood with methanolic extract immobilized the parasites at a concentration of $9 \mathrm{mg} / \mathrm{ml}$. In vivo study also showed the aqueous extract at 50,100, 200 and $300 \mathrm{mg} / \mathrm{Kg}$ body weight were parasite free for 1,5,7 and 14 days respectively. The effect of the extract appeared to be dose dependent. The results showed that Ximenia Americana had in vitro and in vivo efficacy by suppressing the growth of the parasites followed by a relapse.
\end{abstract}

Keywords: Ximenia americana, In vitro and in vivo activity, Trypanosoma congolense

\section{Introduction}

African trypanosomosis is a vector-borne parasitic disease which is causing major health and economic problems in rural sub-Saharan Africa, affecting humans and livestock. Trypanosoma is known to render approximately a quarter of African arable land mass unsuitable for profitable livestock farming (Molyneux, 1997). It causes the death of well over 3 million cattle annually with an estimated lost potential of \$ 6-12 billion US dollars (Mortelmans, 1986; ILRAD, 1994). The prevalence rate is in excess of $70 \%$ in some villages in the Democratic Republic of the Congo according to WHO (2000).

Chemotherapy and chemoprophylaxis by trypanocides using the salts of isometamidium, homidium and diminazene form the most important aspect of control and eradication of trypanosomoses (Leach and Roberts, 1981; Kinabo, 1993; Anene, et. al. 2001). Recent surveys in Eastern and Southern Africa (Ndung'u et al., 1999) and in West Africa (McDermott et al., 2000; Maikai et al., 2007) have shown that the prevalence of trypanocidal drug resistance might even be higher than hitherto expected. Unfortunately the use of these trypanocides is beset by numerous limitations, including toxicity of the drugs, lengthy parenteral administration, unaffordability of the drugs to the resource poor rural farmer, and development of resistance by the parasites and exhibition of antigenic variation which hampers vaccine production (Kuroe, 1993; Doua and Yapo, 1993; Donald, 1994; Anene, et. al. 2001).

These factors emphasize the need for research into a more comprehensive, formidable and cheaper sources of anti-trypanosomal agents. According to the World Health

Organization more than $80 \%$ of the world population still relies on herbal medicines as their primary source of health care. In an effort to discover new lead compounds for infectious diseases, researchers are focusing on plant materials which contain array of diverse chemical substances they have which have biological and physiological properties. Ximenia americana "Wild plum or Plum" in English or locally called "Tsada" in Hausa and "Chabbuli" in Fulani is a bushy and spiny shrub, $4-5 \mathrm{~m}$ high with an open crown. The fruits are green but turn golden yellow or red. The plant is claimed to possess medicinal properties in treatment of fever, jaundice, impotence (Arbonnier, 2004). The stem bark has been reported (Maikai et al., 2008) to contain varying amounts of alkaloids, tannins, Flavonoids, saponnins and cardiac glycosides.

The aim of this study was to verify whether the claimed usage of the plant to treat animal trypanosomiasis could be scientifically confirmed. 


\section{Materials and methods}

\subsection{Collection of plant Material}

The bark of Ximenia Americana was collected from Afaka village $35 \mathrm{~km}$ to Kaduna $\left(11^{\circ} 10^{\prime} \mathrm{N}, 7^{\circ} 38^{\prime}\right.$ E) and taken to Department of Biological Sciences, Ahmadu Bello University Zaria for identification the voucher No.1612. The bark was dried at room temperature before crushing into powder then stored in air tight container and kept at $4^{0} \mathrm{c}$ until needed.

\subsection{Parasites}

Trypanosoma congolense ( Federe strain) was obtained from the Nigerian Institute of Trypanosomiasis Research, Vom Plateau State Nigeria and passaged into rat which was subsequently maintained by passages through mice.

\subsection{Plant Extraction}

\subsubsection{Aqueous Extraction}

Two hundred (200) grams of the powdered bark was boiled in $1000 \mathrm{ml}$ of distilled water for an hour. It was then filtered hot through a muslin cloth before further filtrations using a whatman No. 1 filter paper. The filterate was concentrated in hot air oven at $50^{\circ} \mathrm{c}$ for two days and subsequently air dried. The extract was pounded using pestle and mortar into powder and stored in air tight container and kept at $4^{\circ} \mathrm{C}$ till needed.

\subsubsection{Methanolic extraction}

Two hundred (200) grams of the powdered bark was extracted in $600 \mathrm{ml}$ of methanol in a soxhlet apparatus for $12 \mathrm{~h}$. The extract was concentrated in a rotary evaporator and subsequently the filterate air dried and stored at $4^{\circ} \mathrm{C}$.

\subsection{Experimental animals}

A total of 30 apparently healthy male albino mice ten to twelve weeks old, weighing on the average $27.2 \mathrm{~g}$ were used. The animals were kept in clean plastic cages in a $12 \mathrm{~h}$ light /dark cycle and fed with specially prepared diet made from chick grower's mash, groundnut and flour. Water was given ad libitum and the cages cleaned every week, throughout the duration of the work. A standard protocol was observed in accordance with the Good Laboratory Practice (GLP) Regulations of the WHO (1998). The animal Laboratory care of (CCAC, 1993) was strictly followed.

\subsection{Infection of the mice}

Blood was collected from a mice heavily infected with T.congolense and immediately diluted with sterile buffered phosphate saline ( $\mathrm{pH} 7.2$ ). Healthy mice were injected with $1 \times 10^{3} T$. congolense per $\mathrm{ml}$ of blood intraperitoneally. Evaluation of parasitemia was done daily till parasites were detected microscopically as described by Herbert and Lumsden (1976).

\subsection{In vitro activity of the extracts}

Blood was harvested from a donor mice at peak parasitaemia $\left(10^{8}\right.$ parasites per $/ \mathrm{ml}$ of blood $)$ using a syringe containing $0.1 \mathrm{ml}$ EDTA with phosphate buffer saline glucose.

The in vitro experiment involved incubating $30 \mu 1$ of infected blood with $10 \mu 1$ of the different plant fractions in a 96- well microtiter plates (Flow laboratories Inc. Mclean, Virginia 22101, USA) at $37^{\circ} \mathrm{c}$.

Each fraction / reference drug (Diminavet ${ }^{\mathrm{R}}$ ) was tested at concentrations of $9 \mathrm{mg}, 6 \mathrm{mg}, 3 \mathrm{mg} / \mathrm{ml}, 100 \mu \mathrm{g}$ and $50 \mu \mathrm{g} / \mathrm{ml}$ prepared by serial dilution. The extracts were initially dissolved in sterile water / DMSO and filtered before the serial dilution; each concentration was tested in duplicate. Control / reference wells were incubated with phosphate buffer saline and Diminavet ${ }^{\mathrm{R}}$ respectively. At the end of every 5 minutes for a period of $2 \mathrm{hrs}$, the titer wells were examined at 5minutes interval under (X400) objective for cessation in motility /change of morphology of the parasites in comparison to the control.

\subsection{In vivo activity of the extracts}

A total of 30 mice were injected intraperitoneally with a dose of $1 \times 10^{4} T$. congolense. Parasitemia was daily monitored for 4 days prior to treatment as described (Herbert and Lumsden, 1976). The mice were later divided into six groups (A, B, C, D, E, and F) consisting of five mice each. The methanolic extract was given intraperitoneally at doses of $50,100,200$, and $300 \mathrm{mg} / \mathrm{kg}$ body weight daily to groups $\mathrm{B}, \mathrm{C}, \mathrm{D}, \mathrm{E}$ and F respectively, on the fourth day post infection, after parasites were detected from the tail vein of the mice. 
Treatment was done intraperitoneally twice daily for six days. Group A, which served as control were injected with distilled water. Group F were administered with standard drug Diminavet ${ }^{\mathrm{R}}$ ( $3.5 \mathrm{mg} / \mathrm{kg}$ body weight) was administered only once.

The mice were daily monitored for parasitemia for 4 weeks by microscopically examining blood from the tail vein of the animals (Herbert and Lumsden, 1976).

Mice surviving for more that 30 days after the death of the last control and also having no parasite in their blood smears were considered cured (Bachi et al. 1992).

\subsection{Statistical analysis}

The data was analysed as means \pm standard deviation and the differences between the means determined at the $5 \%$ level of significance using (Armitage, 1980)

\section{Results}

Table 1 shows the in vitro effect of various concentrations of aqueous and methanolic extracts of Ximenia americana on motility of $T$. congolense. The aqueous and methanolic extract showed activity. The result however, revealed that the methanolic extract took 45 minutes at $9 \mathrm{mg} / \mathrm{ml}$ to immobilize the parasites while the aqueous took 52 minutes at $9 \mathrm{mg} / \mathrm{ml}$. While the standard drug Diminavet ${ }^{R}$ immobilize the parasite after 20 minutes at $100 \mu \mathrm{g} / \mathrm{ml}$. The control, (phosphate buffer saline (PBS)) still showed very active motile parasites at the end of 120 minutes. The methanolic extract was used for in vivo experiment since it showed higher activity compared to the aqueous extract. Parasites were detected in all the groups 3 days after infection (Table 2). The in vivo experiment showed mice infected and not treated (Group A), died after 8th day post infection. Group B, C, and D showed parasite clearance for 2, 3 and 3 days respectively, however the mice in Group B,C and D all died before the 30th day as a result of reappearance of parasites. Group E treated at $300 \mathrm{mg} / \mathrm{kg}$ body weight had parasite clearance for 14 days followed by a relapse. In contrast, intraperitoneal injections of Diaminezene aceturate at $3.5 \mathrm{mg} / \mathrm{kg}$ body weight (Group F), completely cleared the parasite from the circulation day 1 after treatment (Table 2).

\section{Discussion}

Trypanosomiasis continues to be the most neglected disease of modern times and described as a poor man's disease. The cessation or drop in motility of trypanosomes in extract treated blood compared to the parasite loaded control blood with no extract was taken as a measure of anti-trypanosomal activity. The efficacy of the extract was assessed on the basis of differences in parasite population. The in vivo experiment was conducted to support the evidence of efficacy of the methanolic extract in vitro. The extract at $300 \mathrm{mg} / \mathrm{kg}$ body weight was able to suppress the establishment of the parasites, suggest the dose dependent nature of the extracts. It also suggests that the dose was more efficacious in suppressing the establishment of parasitemia. That the anti-trypanosomal effect is attributable to the methanolic extract is confirmed by the death of the control group left untreated. The result appears to agree with similar work done with other plants (Igweh and Onabanjo, 1989; Freiburghaus et al, 1996; Nok et al, 1996; Awotunde, 2002; Mbaya et al., 2007). The anti-trypanosomal activity of the extracts could be as a result of certain phytochemicals present in the extract. Possible relapse could be as a result of central nervous system involvement. The present investigation has discovered that the methanolic portion of the stem bark extracts of Ximenia Americana had anti-trypanosomal activity by suppressing the establishment of parasitemia. Hence the study supports the traditional usage of this plant.

The methanolic portion of the extract of Ximenia Americana is currently been investigated for fraction with activity.

\section{References}

Amitage, D. (1980). Statistical methods in Medical Research $1^{\text {st }}$ ed. Blackwell Scientific publication London. Pp 214.

Anene, B.M., Onah, D.N \& Nawa, Y. (2001). Drug resistance in pathogenic African trypanosomes: What hopes for the future? Veterinary Parasitology, 96:83-100.

Anosa, V.O. (1988). Haematological and biochemical changes in human and animal Trypanosomiasis. I. Revue. Elev. Med. Vet. Pays Trop, 41 (1): 65 -78.

Arbonnier, M. (2004). Trees, Shrubs and lianas of West African dry zones. Margraf Publishers CIRAD GMBH,MNHN. 
Atawodi, S.E., Bulus, T., Ibrahim, S., Ameh, D.A., Nok, A.J., Mamman, M \& Galadima M. (2003). In vitro trypanocidal effect of methanolic extract of some Nigerian Savannah plants. African Journal of Biotechnology, Vol. 2 no. 9. 317- 321 .

Awotunde, J.O. (2002). Trypanocidal effect of aqueous and ethanolic leaf extract of Ricinus Communis on Trypanosoma brucei invivo. The Zoologist, 1: (1) 95 -99.

Bachi, CU., Yarlet, N., Goldberg, B., McCann, P.P., Bitoriti, A.J., \& Sjoerdsma, A. (1992). Cure of murine Trypanosoma brucei rhodesiense infections with s - adenosyl decarboxylase inhibitor. Antimicrob. Agents Chemothera, 36: 2736 - 2740 .

Donald, A.D. (1994). Parasite, animal Production and Sustainable development. Vet. Parasitol, 54, 7-47.

Doua, F., \& Yapo, F.B. (1993). Human Trypanosomiasis in the Ivory Coast - Therapy and Problems. Acta Tropica, 54, 163 - 168.

Freiburghaus, F., Kaminsky, R., Nkuna, M.H.N., \& Brun, R. (1996). Evaluation of African medicinal for their in vitro trypanocidal activity. Journal of Ethnopharmacology, 55: 1- 11.

Herbert, W.J., \& Lumsden, W.H.R. (1976). Trypanosoma brucei. A rapid matching method for estimating the host's parasitemia. Experimental Parasitology, 40, 427 - 431.

Igweh, A.C., \& Onabanjo, A.O. (1989). Chemotherapeutic effect of Annona Senegalensis in Trypanosoma brucei brucei. Annals of Tropical medical Parasitology, vol. 85 no. 5. 527-534.

ILRAD. (1994). Trypanosomiasis. International Laboratory for Research on Animaldiseases. Reports, Nairobi. 21-29.

Kaminsky,F., Nkuna, M.H.N.\& Brun,R. (1996). Evaluation of African medicinal for their invitro trypanocidal activity. J. Ethnopharm, 55: 1-11.

Kinabo, L.D.B. (1993). Pharmacology of existing drugs for Animal Trypanosomiasis. Acta Trop, 54, 169 -183.

Kuzoe F. (1993). Current Situation of African Trypanosomiasis. Acta Tropica, 54, 153 - 162.

Leach, T.M., \& Roberts, C.J. (1981). Present status of Chemotherapy and Chemoprophylaxis of Animal Trypanosomiasis in the eastern hemisphere. Pharm.Therap, 13, 91-147.

Maikai V.A., Nok A.J., Adaudi A.O., \& Alawa C. (2008). In vitro antitrypanosomal Activity of aqueous and methanolic crude extracts of stem bark of Ximenia americana on Trypanosoma congolense. Africa Journal of Biotechnology, vol.2(3): 055- 058.

Maikai, V.A., Salka, M.N., Adeiza, A.A., \& Makeri, H.K. (2007). Assessment of Isometamidium chloride and diminazene aceturate in laboratory mice infected with field isolates of $T$. congolense from naturally infected cattle. Journal of Production Agriculture and Technology, 3(1) 147 - 152.

Mbaya, A.W., Nwosu, C.O., \& Onyeyili P.A. (2007). Toxicity and anti trypanosomal effects of ethanolic extract of Butyrospermum paradoxum (sapotaceae) stem bark in rats infected with Trypanosoma brucei and Trypanosoma congolense. Journal of Ethnopharmacology, 111:526-530.

McDermott, J. J., Sidibe, I., Bauer, B., Diarra, B., Clausen P.H., Woitang, T., Ouedraogo,D., Kamuanga, J.M.B., Peregrine, A.S., Eisler, M.C.,\& Mehlitz, D. (2000). Field studies on the development and impact of drug resistant animal trypanosomes in market oriented production systems in the southern Guinea Zone of West Africa. Newsletter No2 of EU concerted Action on.

Molyneux, D.H. (1997). Current public status of the Trypanosomiasis and Leishmaniasis In Hide, G. Mottram, JC; Coombs GH; Holmes, PH (Eds), Trypanosomiasis and Leishmaniasis: Biology and control. CAB International, Wallingford, UK, $39-50$.

Mortelmans, J. (1986). Some economic aspects related to veterinary parasitology. Tropiculture, 4 (3): $112-116$.

Ndung”u, J.M., Murrilla, G.A., Mdachi, R.M., Mbwambo, H., Sinyangwe, L., Machila, N., Delespaux, V., Geerts, S., Brandt, J., Peregrine, A.S., McDermott, J.J., Holmes, P.H., \& Eisler, M.C. (1999). Area-wide appraisal of drug resistance in trypanosomes infecting cattle in East and Southern Africa. In: Proceedings of the International Scientific council for Trypanosomiasis Research and Control, $25^{\text {th }}$ meeting, Mombasa, Kenya, 27 Sept- ${ }^{\text {st }}$ October 1999. OAU/STRC.Nairobi.

Nok, A.J., Esievo, K.A.N., Adaudi, A., Ogeshe, S., Gimba, C.E., \& Kabgu, J.A. (1992). Trypanocidal activity of an organotin compound. J. Clin. Biochem. Nutr., 11: 125-130. 
Nok, A.J., Williams, S., \& Onyenekwe, P.C. (1996). Allium sativum induced death of African trypanosomes. Parasitol. Res., 82: 634-637.

Peter, D., Honigberg,B.M. \& Fern, A.M. (1976). An improved method of cryopreservation of Trypanosoma (Nannomonas) Congolense brooden in liquid nitrogen. The Journal of Parasitology, 62 (1): 136-137.

Sepulaveda-Boza,S., \& Cassels, B.K. (1996). Plant metabolite active against Trypanosoma cruzi. Planta med., 62: 98-105.

WHO. (2000). African Trypanosomiasis. In: Report on Global surveillance of Epidemic - prone infectious diseases. $\mathrm{WHO} / \mathrm{CDS} / \mathrm{CSR} / \mathrm{ISR} / 2000$.

Table 1. In vitro test of aqueous and mthanolic extracts of Ximenia americana on motility of $T$. congolense

\begin{tabular}{lllllll}
\hline Plant name & $\begin{array}{l}\text { Family } \\
\text { name }\end{array}$ & $\begin{array}{l}\text { Plant parts } \\
\text { screened }\end{array}$ & $\begin{array}{l}\text { Portion of } \\
\text { extract used }\end{array}$ & $\begin{array}{l}\text { Time } \\
\text { taken to } \\
\text { effect } \\
\text { activity }\end{array}$ & $\begin{array}{l}\text { inhibitory } \\
\text { concentration } \\
\text { (IC) }(\mathrm{mg} / \mathrm{ml})\end{array}$ & $\begin{array}{l}\text { Activity on } T . \\
\text { congolense }\end{array}$ \\
\hline $\begin{array}{llllll}\text { Ximenia } \\
\text { americana }\end{array}$ & Olacaceae & Stem bark & Aqueous & 52 & 9 & + \\
& & Methanol & 45 & 9 & + \\
& & - & 20 & $100 \mu \mathrm{g} / \mathrm{ml}$ & + \\
\hline
\end{tabular}

$+\quad$ active against $T$. congolense

- $\quad$ not active against $T$. congolense

IC- concentration at which no trypanosome with a normal morphology/or motility was found when compared to the controls

Table 2. In vivo activity of methanolic extracts of Ximenia americana

\begin{tabular}{ccccccc}
\hline days & A & B & C & D & E & F \\
$\begin{array}{c}\text { post } \\
\text { infection }\end{array}$ & untreated & $(50 \mathrm{mg} / \mathrm{kg})$ & $(100 \mathrm{mg} / \mathrm{kg})$ & $(200 \mathrm{mg} / \mathrm{kg})$ & $(300 \mathrm{mg} / \mathrm{kg})$ & $(3.5 \mathrm{mg} / \mathrm{kg})$ \\
\hline 3 & $1 \times 10^{4}$ & $1 \times 10^{3}$ & $1 \times 10^{2}$ & $1 \times 10^{4}$ & $1 \times 10^{3}$ & $1 \times 10^{2}$ \\
4 & $1 \times 10^{5}$ & $1 \times 10^{6}$ & $1 \times 10^{6}$ & $1 \times 10^{6}$ & $1 \times 10^{7}$ & $1 \times 10^{6}$ \\
5 & $1 \times 10^{8}$ & $1 \times 10^{8}$ & $1 \times 10^{8}$ & $1 \times 10^{8}$ & $1 \times 10^{7}$ & 0 \\
6 & $2 \times 10^{8}$ & $6 \times 10^{7}$ & $2 \times 10^{8}$ & $2 \times 10^{7}$ & $2 \times 10^{6}$ & 0 \\
7 & $1 \times 10^{9}$ & $1 \times 10^{8}$ & $6 \times 10^{7}$ & $1 \times 10^{7}$ & $1 \times 10^{5}$ & 0 \\
8 & Dead & $3 \times 10^{7}$ & $1 \times 10^{7}$ & $2 \times 10^{5}$ & 0 & 0 \\
9 & Dead & $4 \times 10^{7}$ & $3 \times 10^{6}$ & 0 & 0 & 0 \\
10 & Dead & $3 \times 10^{7}$ & $1 \times 10^{6}$ & 0 & 0 & 0 \\
11 & Dead & $4 \times 10^{6}$ & 0 & 0 & 0 & 0 \\
12 & & $2 \times 10^{6}$ & 0 & $1 \times 10^{6}$ & 0 & 0 \\
13 & & 0 & 0 & $1 \times 10^{7}$ & 0 & 0 \\
14 & & 0 & $1 \times 10^{6}$ & $2 \times 10^{5}$ & 0 & 0 \\
30 & & Dead & Dead & Dead & $1 \times 10^{3}$ & alive \\
\hline
\end{tabular}

Mean determinations 